\title{
fLEX: Flexioa eta LEXikoa aztertzeko test eleanitza (5-10 urteko hamar haur euskaldunen emaitzen azterketa)
}

\author{
(fLEX: multilingual test for assessing inFlection and LEXicon \\ (results from ten Basque-speaking children, ages 5 through 10))
}

Marie Pourquié*

IKER-UMR 5478, PAHU, Baiona, Lapurdi

\begin{abstract}
LABURPENA: Artikulu honen helburua da fLEX aplikazio eleanitzaren motibazioa, egitura, eta funtzionamendua aurkeztea eta, horretan oinarrituta, hamar haur euskaldunengandik bildutako datuak aztertzea. Ahozko bost probak eta orotara 160 estimuluk osatzen dute fLEX, prozesaketa lexikala zein flexionala, ekoizpena eta ulermenean aztertzeko: gauzak eta ekintzak izendatzea; esaldiak ekoiztea eta ulertzea; kasu eta posposizio sintagmak ekoiztea. Aurreikusten zen proba hauek egiteko zailtasunik ez agertzea bost urtetik gorako haurrentzat. 5-10 urte tarteko hamar haur euskaldunek parte hartu dute ikerketan. Emaitzek erakusten dute esaldiak ekoiztea dela emaitza ahulenak dakartzan proba; «ditu» eta «die» aditz laguntzaileak ekoizteko emaitzak apalak direla forma horiek ulertzeko arazo handirik ez den arren; ergatiboa, destinatiboa eta lekuzko genitiboa ekoizteko, beste kasu eta posposizioak ekoizteko baino huts gehiago agertzen dira. Datuen kantitatezko eta kalitatezko deskribapena egiten da, prozesaketa flexionalean eta lexikalean puntu ahulak erakutsiz. Haurren garapen tipikoaren ahuleziak definitzea ezinbestekoa da hizkuntza-arazoak diagnostikatzeko garaian. Psikohizkuntzalaritzaren ikuspegitik corpus baliagarri bat eskaintzeaz gain, euskaraz hizkuntza aztertzeko tresnak garatzeko beharra azpimarratzen da.
\end{abstract}

HITZ GAKOAK: lexikoa, morfosintaxia, flexioa, egitura argumentala, hizkuntzaren ekoizpena eta ulermena, psikolinguistika, euskara, eleaniztasuna, hizkuntza aztertzeko tresnak.

ABSTRACT: The aim of this paper is to present the purpose, structure and functioning of the fLEX software and to examine the data collected from the assessment of ten Basque-speaking children. 160 stimuli divided in five oral tasks make up fLEX, which assesses lexical and inflectional processing in production and comprehension: object and action naming; sentence production and comprehension; and, case and postpositional phrase production. It was predicted that no difficulty would emerge in performing these tasks for children older than 5. Ten Basquespeaking children, ages 5 through 10, participated in the study. Of the five tasks, the poorest results were found in the sentence production task. The verb auxiliaries «ditu» and «die» were specifically prone to errors in production but not in comprehension. Ergative, destinative and local genitive case production was more problematic than the production of other cases. Data are described quantitatively and qualitatively, by pointing out weaknesses in lexical and inflectional processing. Defining typically developing children' weaknesses is crucial in order to diagnose language disorders. In addition to providing a useful corpus from a psycholinguistic perspective, the goal of this paper is to emphasize the need for developing language assessment tools in Basque.

KEYWORDS: lexicon, morphosyntax, inflection, argument structure, language production and comprehension, psycholinguistics, Basque, multilingualism, language assessment tools.

\footnotetext{
* Harremanetan jartzeko / Corresponding author: Marie Pourquié, IKER-UMR 5478 (CNRS, Montaigne Bordele, PAHU) Euskararen eta euskal testuei buruzko ikerketa gunea, Errobiko Campusa, Gaztelu Berria Paul Bert plaza, 15 (64100 BaionaLapurdi). - mariepourquieweb@gmail.com - https://orcid.org/0000-0002-6159-6106.

Nola aipatu / How to cite: Pourquie, Marie (2019). «fLEX: Flexioa eta LEXikoa aztertzeko test eleanitza (5-10 urteko hamar haur euskaldunen emaitzen azterketa)n; Ekaia, 36, 2019, 331-351. (https://doi.org/10.1387/ekaia.19723).

Jasoa: 15 maiatza, 2018; Onartua: 25 otsaila, 2019

ISSN 0214-9001 - eISSN 2444-3255 / (c) 2019 UPV/EHU

(c) (1) (2) () Obra hau Creative Commons Atribución 4.0 Internacional-en

BY $N$ SA lizentziapean dago
} 


\section{SARRERA}

Hizkuntza-arazoak dituzten populazioak euskaraz aztertzeko tresnak eskasak direla eta, fLEX tresna eleanitza garatu da: euskaraz, frantsesez eta gaztelaniaz, hain zuzen Euskal Herriko egoera linguistikoari egokitzeko asmoz. Artikulu honen helburua da fLEX testa aurkeztea, bai eta horretan oinarrituta hamar haur euskaldunengandik bildu diren emaitzen berri ematea.

\section{1. fLEXen motibapena}

fLEXen motibapen nagusiak hauek dira:

- hizkuntza tipikoa edo atipikoa duten haur edota heldu euskaldunengandik datuak biltzeko tresna izatea

- sindrome batzuen (adb. afasia agramatikoa, disfasia) ezaugarri nagusitzat hartzen den aditz prozesaketaren arazoak aztertzea

- beste hizkuntzekiko (frantsesa eta gaztelaniarekiko) konparaketak ahalbidetzea, bai eta elebidunak bi hizkuntzetan aztertzea, tresna berean oinarrituta.

Euskal gramatika interesgarria da aditz prozesaketa aztertzeko, ekoizpen eta ulermenean. Aditz forma perifrastikoaren bidez erraz ikus daiteke arazoak lexikalak edo funtzionalak diren. Izan ere, orokorrak badira, forma perifrastiko osoa kaltetua izango da, baina lexikala edo funtzionala baldin bada, orduan parte lexikala bakarrik edo aditz laguntzailea bakarrik kaltetua izango da. Komunztadura pluripertsonala (adb. nor-nori-nork motako aditzak) oso egokia da ikusteko aditz laguntzaile ezberdinek ber zailtasuna dakarten. Frantsesez, gaztelaniaz edo ingelesez ez bezala, euskaraz aditz jokabidea aldatzen da aditzaren egitura argumentalaren arabera. Aditzak infinitiboan direnean hizkuntzen arteko ezberdintasunik ez da nabarmentzen baina aditzak jokatzen direnean, bai (ikus 1. eranskina).

«Pro-drop» ezaugarria oso egokia da aditz jokatuen ahozko ulermena aztertzeko. Adibidez, izenordaina isilduz, «irakurtzen du vs. irakurtzen dute», «lee vs. leen» eta antzeko esaldiak bereizteko ezinbestekoa da aditz flexioa deskodetzea. Esaldi horiek ingelesera itzulita «He reads vs. They read», izenordainean ere oinarritu daiteke (He vs. They). Frantsesa ez da pro-drop, baina pro-drop kontestu bat sor daiteke frantsesaren ezaugarri morfofonologikoak erabiliz. Adibidez, «il/ils» (hura/haiek) izenordainak homofonoak dira baldin eta kontsonante batez hasten den aditz batek jarraitzen baditu (adibidez : il lit [ili] / ils lisent [iliz]). Kasu horretan prodrop efektu bat sortzen da. Baina bokalez hasten den aditz batek jarraitzen baditu, «liaison fonologikoa» gertatzen da eta beraz aditz flexioan ez ezik, liaison fonologikoan ere oinarritu daiteke bi esaldi horiek bereizteko (il écrit [ilekri]/ils écrivent [ilzekriv]). Aditz flexioaren ahozko ulermena 
aztertzen duen proba bat sortu nahi bada, ezinbestekoa da hizkuntzetako ezaugarri morfofonologikoak ongi kontrolatzea.

Azkenik, euskal morfologia eranskaria baliagarria zaigu aditz morfologia flexionalaren prozesaketarekin konparatzeko, eta bien arteko disoziazio bat agertzen den aztertzeko: adibidez, datibodun aditz forma bat ekoiztea zaila izatea, baina datibodun kasu sintagma bat ez (ematen dio vs. oiloari). Gainera, hizkuntzen arteko konparaketak ahalbidetzen du sistema morfologiko ezberdinetan zailtasunak berdinak diren ikustea: Oilari / à la poule/ a la gallina. Hizkuntza aniztasuna baliagarria da proba zehatzak sortzeko, bai eta sindromeetako sintomatologia konparatzeko. Hizkuntzen arteko disoziazioak aurkitzen badira, hala nola morfologia eranskariarekin (morfema lotuak) arazorik ez agertzea, baina determinatzaile eta preposizioen erabilpenean bai (morfema libreak), horrek aditzera ematen du hizkuntzetako sistema morfologiko ezberdinak burmuineko sare ezberdinetan prozesatzen direla.

\section{2. fLEXen egitura}

fLEX, hizkuntzen arteko konparaketa ahalbidetzeaz gain, haur eta helduentzat diseinatua izan da hizkuntzaren prozesaketa hainbat populaziotan aztertzeko asmoz [1]. Tresna honek ez ditu, hala ere, hizkuntzaren atal guztiak eta modalitate guztiak aztertzen. Ikerketa galdera zehatz batzuei erantzuteko diseinatua izan da eta izen eta aditzen prozesaketa lexikala eta flexionala aztertzen ditu bereziki. Disfasia edota afasia agramatikoaren ezaugarri nagusietariko bat da aditzak erabiltzeko zailtasunak izatea [2, 3]. Hizkuntza askotan deskribatua izan da, eta euskaraz ere bai [4, 5]. Hala ere, euskaraz datu gehiago bildu behar dira ikerketak sakontzeko. Gainera, literaturan eztabaidak daude aditzak erabiltzerakoan zailtasunak nondik datozen definitzeko, ez dago argi ulermena ekoizpena bezain arazotsua den, eta aditz jokatuekin arazoak diren bereziki ala izen kategoriarekin ere bai.

Hizkuntzalaritza klinikoko literaturan oinarrituz eta euskara, frantsesa eta gaztelaniaren ezaugarri gramatikaletan oinarrituz, ondoko puntuak aztertzeko diseinatua izan da fLEX:

1. hainbat aditz motaren prozesaketa lexikala eta morfosintaktikoa;

2. aditz jokatuen ekoizpena eta ulermena;

3. izen soilen ekoizpena eta posposizio/preposizio-sintagmen ekoizpena.

1. irudiak fLEXen antolaketa erakusten du: 1) fLEXeko proba guztiak ahozkoak dira; 2) hiru hizkuntzatan diseinatua da; 3) hitz eta esaldi mailak aztertzen ditu; 4) maila lexikoa (urdinez) eta morfosintaktikoa (gorriz) aztertzen ditu; 5) izen eta aditzen erabilpena, testuinguru gramatikaletik 
kanpo eta haren barne aztertzen ditu; 6) egitura argumental ezberdineko aditzen erabilpena aztertzen du.

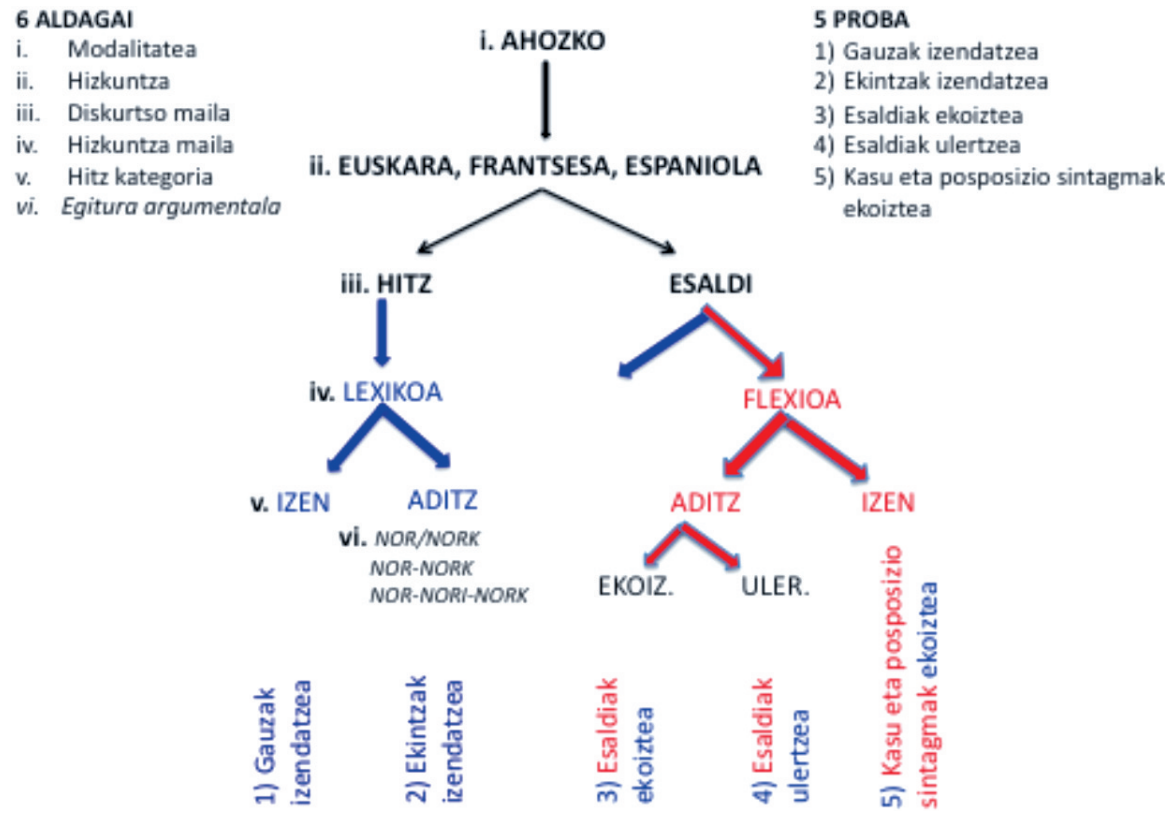

1. irudia. fLEX egituraren eskema.

Guztira, ahozko bost proba daude: maila lexikoko bi (urdinez: gauzak eta ekintzak izendatzea) eta maila morfosintaktikoko hiru (gorriz: esaldiak ekoiztea eta ulertzea, kasu eta posposizio sintagmak ekoiztea). Aditzen ekoizpen semantikoa vs. morfosintaktikoaren arteko disoziazioa aztertzeko, baliagarria izango da 2 . eta 3 . probetako emaitzak alderatzea, aditz jokatuen ekoizpena eta ulermenaren arteko disoziazioa aztertzeko 3. eta 4. probetako emaitzak alderatzea, eta izen soilen ekoizpena eta posposizio/ preposizio-sintagmen ekoizpenaren arteko disoziazioa aztertzeko, 5. eta 1. probetako emaitzak alderatzea.

\subsection{Ikerketaren helburua eta aurreikuspenak}

fLEXen oinarrituta disfasiaren sintomak euskaraz definitzeko, beharrezkoa da hizkuntzaren garapen tipikoa (GT) duten haur euskaldunen emaitzak aztertzea. Horrek balioko du, batetik, testa egingarria den ikusteko (adibidez, kontsignak eta irudiak ulergarriak diren frogatzeko), bai eta probak egiteko zailtasunak agertzen ote diren antzemateko. GT duten haurrak direla jakinda, ondorioztatuko da identifikatuko diren zailtasunak hiz- 
kuntz-patologia baten manifestazioak ez direla. Testak GT haurren jarreran sortzen dituen zailtasunak kontuan hartzea ezinbestekoa da patologia duten haurrak aztertu ahal izateko, eta zertan ezberdintzen diren definitu ahal izateko $[6,7]$.

Hizkuntza-jabekuntzari buruzko literaturak dioenez, haurra euskal izen eta aditzaren morfologiaz jabetzen da bost urte baino lehen [8-12]. Euskal aditz morfologia konplexuaz progresiboki jabetzen da, eta absolutiboarekiko komunztadura, ergatiboarekiko eta datiboarekiko komunztadura baino lehen egiten da [13, 14]. Kasu deklinabideari dagokionez, euskara H1 duten haurretan 2-3 urte inguruan garatzen bada, ergatibo marka ahula ager daiteke, eta haurraren inguruan euskaraz zenbat entzuten den edo euskara $\mathrm{H} 1$ ala $\mathrm{H} 2$ den faktoreek eragiten dute. Ikerlanek erakusten dute euskararen presentzia mailak eragina duela haurraren hizkuntzaren garapenean [15-17].

Ikerketa honen helburua da 5-10 urte tarteko haurrek, fLEX testa pasatzean zailtasunak erakutsiko zituzten ikustea, eta zailtasunak probarekin edo haurren ezaugarriekin lotzen diren aztertzea. Aurreikusten zen adin tarte horretako haurrak izen eta aditzak, testuinguru gramatikal baten barne ala kanpo, ekoizteko edota ulertzeko gai direla. Artikulu honek eskaintzen du ingurumen linguistiko ezberdina duten hamar haur euskaldunengandik bildu diren azterketa deskriptibo bat, puntu hauek bereziki aztertuz:

- aditzen ekoizpena maila semantiko-lexikalean eta morfosintaktikoan;

— aditz jokatuen ekoizpena eta ulermena;

- kasu eta posposizio sintagmen ekoizpena.

\section{METODOA}

\subsection{Parte-hartzaileak}

Ikerketa horretan, 5-10 urte tarteko 14 garapen tipikoko haur euskaldunek parte hartu dute (horietatik 6 mutil) ${ }^{1}$. Denek hiru urte baino lehenagotik ikasi dute euskara, baina ez dute denek ber ingurumen linguistikoa. Euskaraz maila apalegia erakusteagatik, eta proba bat ez burutzeagatik, lau partaideren emaitzak baztertu ziren. 1. taulak partaideei buruzko informa-

${ }^{1}$ Lagin hau ikerketa baten azpi-lagina da (Author, «Cross-Language and Cross-Population Verb Processing», Marie Curie Actions, FP7-PEOPLE-2011-IOF) 88 pertsonak parte hartu zuten: 30 haur eta 30 heldu (20 euskara-gaztelania elebidun; 20 frantsesdun; 20 heldu gaztelaniadun); 5 afasiadun ( 2 frantses; 2 euskaldun; 1 gaztelaniadun); hizkuntza garapeneko arazoak dituzten 23 haurrek ( 7 frantsesdun, 8 gaztelaniadun; 8 euskara-gaztelania elebidun) 
zio orokorra biltzen du (adina, sexua); euskararen erabiltzeari buruzko informazioa: noiztik erabiltzen duten; erabilpen orokorra (\%); aita-amekin erabiltzen duten; euskararen ezagutzari buruzko informazioa: haien mintzatzeko eta ulertzeko mailaren autoebaluaketa (/10).

1.taula. Hamar haurren ezaugarriak.

\begin{tabular}{|c|c|c|c|c|c|c|c|c|c|c|}
\hline Partaidea & $\begin{array}{c}\mathrm{CcB} \\
02\end{array}$ & $\begin{array}{c}\mathrm{CcB} \\
05\end{array}$ & $\begin{array}{c}\mathrm{CcB} \\
09\end{array}$ & $\begin{array}{c}\mathrm{CcB} \\
03\end{array}$ & $\begin{array}{c}\mathrm{CcB} \\
04\end{array}$ & $\begin{array}{c}\mathrm{CcB} \\
06\end{array}$ & $\begin{array}{c}\mathrm{CcB} \\
07\end{array}$ & $\begin{array}{c}\mathrm{CcB} \\
01\end{array}$ & $\begin{array}{c}\mathrm{CcB} \\
08\end{array}$ & $\begin{array}{c}\mathrm{CcB} \\
10\end{array}$ \\
\hline Adina & $5 ; 7$ & $5 ; 9$ & $6 ; 2$ & $6 ; 7$ & $6 ; 11$ & $7 ; 8$ & $9 ; 2$ & $9 ; 4$ & $9 ; 7$ & 10 \\
\hline Sexua & M & $\mathrm{F}$ & M & M & $\mathrm{F}$ & M & $\mathrm{F}$ & M & $\mathrm{F}$ & $\mathrm{F}$ \\
\hline Ama hizkuntza & Gazt & Eusk & Eusk & Eusk & Eusk & Gazt & Gazt & Gazt & Gazt & Eusk \\
\hline $\begin{array}{l}\text { Euskara noiztik } \\
\quad \text { (urtez) }\end{array}$ & 1 & 0 & 0 & 0 & 0 & 1 & 1 & 2 & 3 & 0 \\
\hline $\begin{array}{c}\text { Erabilpen } \\
\text { orokorra }(\%)\end{array}$ & 50 & 90 & 70 & 40 & 40 & 40 & 40 & 40 & 30 & 30 \\
\hline $\begin{array}{c}\text { Mintzatzeko } \\
\text { gaitasuna (/10) }\end{array}$ & 7 & 10 & 10 & 8 & 7 & 5 & 5 & 7 & 6 & 7 \\
\hline $\begin{array}{c}\text { Ulertzeko } \\
\text { gaitasuna (/10) }\end{array}$ & 7 & 10 & 10 & 8 & 7 & 6 & 5 & 7 & 6 & 7,5 \\
\hline Aitarekin & Gazt & Eusk & Gazt & Eusk & Gazt & $\begin{array}{l}\text { Gazt/ } \\
\text { Eusk }\end{array}$ & $\begin{array}{c}\text { Gazt, } \\
\text { Ingl }\end{array}$ & Gazt & Gazt & Eusk \\
\hline Amarekin & Gazt & Eusk & Eusk & Eusk & $\begin{array}{l}\text { Gazt/ } \\
\text { Eusk }\end{array}$ & $\begin{array}{l}\text { Gazt/ } \\
\text { Eusk }\end{array}$ & Gazt & Gazt & Gazt & Eusk \\
\hline
\end{tabular}

Gazt. $=$ Gaztelania; Eusk. $=$ Euskara Ingl. = Inglesa .

\subsection{Materiala: probak eta estimuluak}

Psikohizkuntzalaritzaren alorrean, «estimulu» deitzen zaio erantzun bat eragiten duen gertakari bati. Adibidez, irudi bat ikusteak irudi mental bat pitz dezake norberaren gogoan, eta irudiari dagokion hitz bat ere bai. Ikerketa psikolinguistikoan bai eta hizkuntzalaritza klinikoan, irudiak estimulu bezala erabiltzen ohi dira prozesaketa lexikoa eta gramatikala aztertzeko.

fLEXeko estimuluak kolorezko eta forma berdineko irudiak dira, eta haur zein helduentzat egokiak izateko diseinatuak izan dira (ikusi ondoko parteetako adibideak). Flex-eko proba guztiak ahozkoak dira: ekoizpeneko probetan, hitz eta esaldiak ahoz esatea eskatzen da, eta, ulermeneko probetan, entzundakoa ulertzea. Aplikazio bat sortua izan da irudiak eta kontsignak automatikoki pasatzeko bai eta partaideen erantzunak zuzenean grabatu ahal izateko (1). 


\subsubsection{Gauzak eta ekintzak izendatzeko estimuluak ( $f L E X 1$ eta 2)}

fLEXeko 1. probak («gauzak izendatzea») izenak ekoizteko gaitasuna aztertzeko helburua du, maila semantiko-lexikoan. 30 estimulu ditu. Klase semantiko ezberdinetako gauzak irudikatzen dituzten irudiak erabiltzen dira. Hitzak maiztasun eta luzera ezberdinetakoak dira eta hitz kognatu eta ez kognatuak ere agertzen dira. 2. taulak ekoitzarazi nahi diren izenen zerrenda ematen du (frantsesez eta gaztelaniaz; izen kopuruaren erdia maskulinoa da, bestea femeninoa) eta, horren azpian, izenak ekoitzarazteko erabiltzen den irudi baten adibidea ematen da (2. irudia).

2. taula. fLEX1eko izen zerrenda (guztira $=30$ ).

\begin{tabular}{c|l}
\hline $\begin{array}{c}\text { fLEX1 Klase } \\
\text { semantikoa }\end{array}$ & \multicolumn{1}{|c}{ Gauzak izendatze probako item zerrenda } \\
\hline $\begin{array}{c}\text { Gauzak } \\
\text { denetarik })\end{array}$ & $\begin{array}{l}\text { itsasontzia; koilara; arkatza; aulkia; pilota; autoa; ohea; liburua; izarra; } \\
\text { galtzerdia; lorea; zuhaitza; etxea; labana; txapela }\end{array}$ \\
\hline Gorputz atalak & hanka; besoa \\
\hline Jatekoak & gaileta; azenarioa; sagarra \\
\hline Lekuak & parkea; hondartza \\
\hline Abereak & erlea; txakurra; txerria; dortoka; oiloa \\
\hline Pertsonak & mutikoa; neska; haurtxo \\
\hline
\end{tabular}

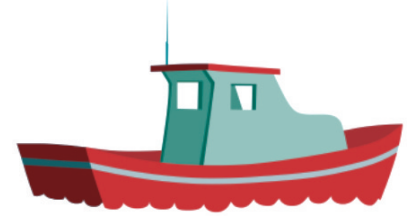

2. irudia. fLEX1 Gauzak izendatze probako estimulu baten adibidea: «itsasontzia».

fLEXeko 2. probak («ekintzak izendatzea») aditzak ekoizteko gaitasuna aztertzeko helburua du, maila semantiko-lexikoan. 30 estimulu ditu. Ekintza ezberdinak irudikatzen dituzten irudiak erabiltzen dira. Aditzak maiztasun $^{2}$ eta luzera ezberdinetakoak dira.

2 Zaila da estimuluen maiztasuna osoki kontrolatzea izendatze probetan, jakinez euskaraz euskalkien arteko ezberdintasunak direla: adibidez EHME datubasean «orraztu» aditzak 5.06 balorea duelarik, «orraztatu» aditzak 0.18eko maiztasuna du. Izenen artean ere: «dordoka» hitzak 0.7 balorea du baina «apoarmatua» hitza ez da aurkitzen. 
3. taulak ekoitzarazi nahi diren aditzen zerrenda ematen du, hainbat egitura argumentaletan sailkatuz (V1: subjektu bat inplikatzen duten hamar aditz; V2: subjektu bat eta objektu bat inplikatzen dituzten hamar aditz; V3: subjektu bat eta bi objektu inplikatzen dituzten hamar aditz); eta horren azpian, aditz mota bakoitza ekoitzarazteko erabiltzen den irudi baten adibidea ematen da (3. irudia).

3. taula. fLEX2ko aditz zerrenda (guztira $=30$ ).

\begin{tabular}{c|l}
\hline Flex2 Aditz mota & \multicolumn{1}{c}{ Ekintzak izendatze item zerrenda } \\
\hline $\begin{array}{c}\text { V1: Nor/Nork aditzak (aditz } \\
\text { inakusatiboak eta inergatiboak) }\end{array}$ & $\begin{array}{l}\text { erre ; erori ; atera ; lotsatu ; handitu ; lo egin ; igeri } \\
\text { egin; irri/barre egin; korrika egin; nigar egin }\end{array}$ \\
\hline $\begin{array}{c}\text { V2: Nor-Nork motakoak (aditz } \\
\text { iragankorrak) }\end{array}$ & $\begin{array}{l}\text { hautsi ; moztu ; lurperatu ; jan ; bildu ; jan ; irakurri ; } \\
\text { bete ; eraiki ; usaindu }\end{array}$ \\
\hline $\begin{array}{c}\text { V3: Nor-Nori-Nork motakoak } \\
\text { (aditz iragankorrak) }\end{array}$ & $\begin{array}{l}\text { eman; saldu; kondatu; bota; kendu; erran/esan; moztu; } \\
\text { ekarri; orraztu; eskaini }\end{array}$ \\
\hline
\end{tabular}
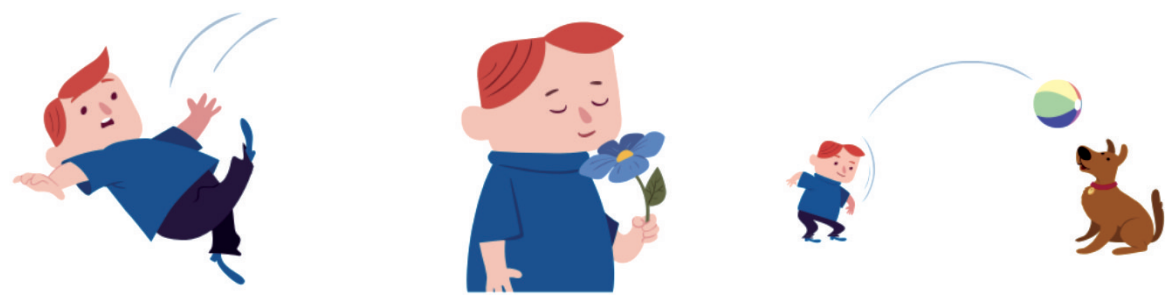

3. irudia. fLEX2 Ekintzak izendatze probako estimulu adibideak: «erori; usaindu; bota».

\subsubsection{Esaldiak ekoizteko estimuluak (fLEX 3)}

fLEXeko 3. probak («esaldiak ekoitzea») aditz jokatuak ekoizteko gaitasuna aztertzeko helburua du, maila semantiko-lexikoan eta morfosintaktikoan. 2. probako aditzak erabiltzen dira, baina aldi honetan aditz soila ekoiztea baino (ekintza izendatzea), esaldi bat ekoiztea eskatzen da; hots, aditza jokatzea (esaldi ekoizpena):

- NOR motako 5 aditz singularrean eta pluralean, da/dira aditz laguntzaileak ekoiztarazteko;

- NOR-NORK motako 5 aditz subjektu singular-objektu singular, subjektu plural-objektu singular, eta subjektu singular-objektu pluralarekin, du/dute/ditu aditz laguntzaileak ekoitzarazteko; 
- NOR-NORI-NORK motako 5 aditz subjektu singular-objektu zuzen singular-objektu ez-zuzen singular eta pluralarekin, dio/die aditz laguntzaileak ekoitzarazteko.

Guztira, 35 estimulu erabiltzen dira zazpi aditz-laguntzaile ezberdin ekoitzarazteko. 4. taulak erakusten du aditz mota, eta ekoitzarazi nahi den aditz laguntzaile mota, eta, horren azpian, aditz jokatuak ekoitzarazteko erabiltzen den irudi baten adibidea ematen da (5. irudia).

4. taula. fLEX3 eta $4 \mathrm{ko}$ aditz eta aditz laguntzaile zerrenda (guztira $=35$ esaldi).

\begin{tabular}{lcc}
\multicolumn{1}{c}{ Flex3 \&4 } & Aditzak (fLEX2tik hartuak) & $\begin{array}{c}\text { Aditz } \\
\text { laguntzaileak }\end{array}$ \\
\hline $\begin{array}{l}\text { Nor motakoak (aditz iragangaitz } \\
\text { inakusatiboak) }\end{array}$ & erre ; erori ; atera ; lotsatu ; handitu & da ; dira \\
\hline $\begin{array}{l}\text { Nor-Nork motakoak (aditz iragan- } \\
\text { korrak) }\end{array}$ & jan ; irakurri ; bete ; eraiki ; usaindu & $\begin{array}{c}\text { du; dute; } \\
\text { ditu }\end{array}$ \\
\hline $\begin{array}{l}\text { Nor-Nori-Nork motakoak (aditz ira- } \\
\text { gankorrak) }\end{array}$ & eman; saldu; kondatu; bota; kendu; & dio ; die \\
\hline
\end{tabular}
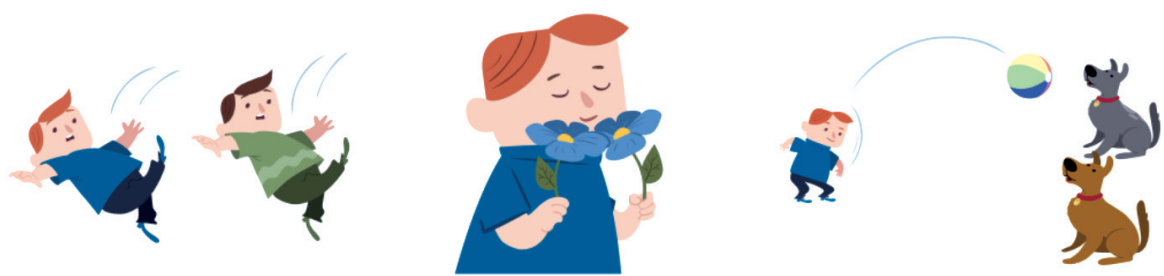

4. irudia. fLEX3 Esaldien ekoizpeneko probako estimulu adibideak: «Erortzen dira»; «Usaintzen ditu»; «Botatzen die».

\subsubsection{Esaldiak ulertzeko estimuluak (fLEX 4)}

fLEX-eko 4. probak («esaldiak ulertzea») aditz jokatuak ulertzeko gaitasuna aztertzeko helburua du, maila semantiko-lexikoan eta morfosintaktikoan. 3. probako esaldiak erabiltzen dira $(=35$, ikus 3 . taula), baina isiltzen dira subjektuak (euskararen pro-drop parametroa erabiliz) aditz flexiotik kanpoko indizeak isilarazteko. Hau da, proba horren helburua da aditz flexioan fokalizatzea, adibidez, «egunkaria irakurtzen dute» esaldia entzutean, subjektu plurala-objektu singularra adierazten dela ulertzeko gaitasuna aztertzea. Irudietan oinarritutako proben bidez ulermena aztertzeko, 
aukera bat izan daiteke irudi bat baino gehiago erabiltzea, xede-esaldiari dagokion irudiarekin batera distraitzaileak erabiliz. Psikohizkuntzalaritza esperimentalean, «distraitzaile» deitzen zaio kasurik eman behar ez zaion estimulu edo estimuluaren parte bati. fLEXen aditz flexioa eta lexikoaren ulermena aztertzeko, ulertzekoa den esaldia irudikatzen duen irudiarekin batera, hiru distraitzaile erabiltzen dira: distraitzaile «flexionala», «lexikala» eta «mixtoa». Distraitzaile flexionalak entzundako esaldiak adierazten duen flexioa ez den zerbait irudikatzen du. Distraitzaile lexikoak entzundako esaldiak adierazten duen ekintza ez den zerbait irudikatzen du. Distraitzaile mixtoak entzundako esaldiak adierazten dituen flexio eta ekintza ez diren zerbait irudikatzen du. Xede eta distraitzaile irudiak modu aleatorioan agertzen dira.

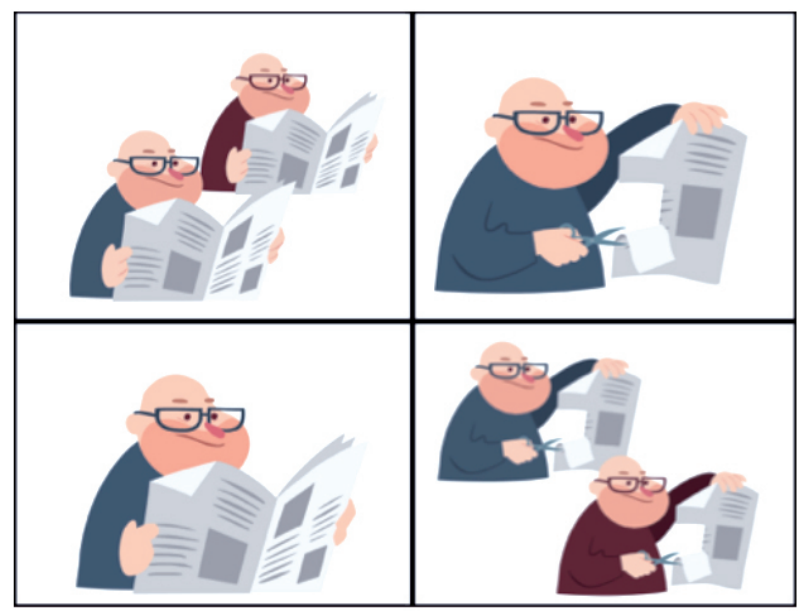

5. irudia. fLEX4 Esaldien ulermeneko probako estimulu adibidea: «Egunkaria irakurtzen dute.» (Xedeirudia: goian ezkerrean; Distraitzaile flexionala: behean ezkerrean; Distraitzaile lexikala: behean eskuinean; Distraitzaile mixtoa: goian eskuinean).

\subsubsection{Kasu eta posposizio sintagmak ekoizteko estimuluak ( $L L E X$ 5)}

fLEXeko 5. probak deklinabide atzizkiak ekoizteko gaitasuna aztertzeko helburua du, maila semantiko-lexikoan eta morfosintaktikoan: «kasu eta posposizio sintagmak ekoiztea» da. 30 estimulu ditu. 1. probako izenak erabiltzen dira testuinguru gramatikal batean. Guztira, 30 estimulu-galdera erabiltzen dira, hamar kasu ezberdin ekoitzarazteko. 5. taulak erakusten ditu kasu motak, galdera-estimuluen adibideak eta ekoiztarazi nahi diren posposizio sintagmak. Eta, horren azpian, posposizio sintagmak ekoitzarazteko erabiltzen den irudi baten adibidea ematen da (6. irudia). 
5. taula. fLEX5eko kasu eta izen zerrenda.

\begin{tabular}{|c|c|c|}
\hline Flex5 Kasua & Estimulu adibidea & Izenak (fLEX1tik hartuak) \\
\hline NORK & Nork jaten du hostoa? & dortokak; erleak; neskak \\
\hline NORI & Nori botatzen dio pilota haurrak? & oiloari; txakurrari; niniari \\
\hline ZER & $\begin{array}{l}\text { Zer botatzen dio txakurrari } \\
\text { haurrak? }\end{array}$ & azenarioa; pilota; lorea \\
\hline NORENA & Norena da sudurra? & txerriarena; niniarena; neskarena \\
\hline NORENTZAT & Norentzat da hezurra? & $\begin{array}{l}\text { niniarentzat; oiloarentzat; } \\
\text { txakurarrentzat }\end{array}$ \\
\hline NOREKIN & Norekin ibiltzen da haurra? & $\begin{array}{c}\text { oiloarekin; txakurrarekin; } \\
\text { labanarekin }\end{array}$ \\
\hline $\mathrm{NON}$ & Non dago txakurra? & etxean; parkean; txapelan \\
\hline NONGOA & Nongoa da balea? & $\begin{array}{l}\text { itsasokoa; oihanekoa; } \\
\text { basamortukoa }\end{array}$ \\
\hline NONDIK & Nondik salto egiten du mutikoak? & aulkitik; sagarretik; itsasontzitik \\
\hline NORA & Nora doa mutikoa? & etxera, parkera; hondartzara \\
\hline Guztira & $3 \times 10$ & 30 \\
\hline
\end{tabular}

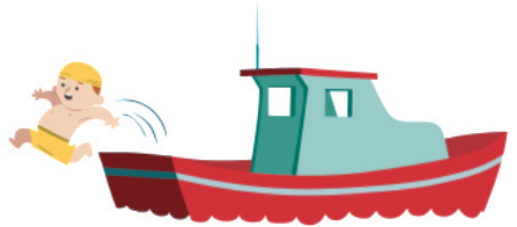

6. irudia. fLEX5 Posposizioen ekoizpeneko probako estimulu adibidea: «Itsasontzitik».

\subsection{5. fLEX testa laburbilduz}

fLEXek bost proba ditu : lehen bi probek (gauzak eta ekintzak izendatzea) maila semantiko-lexikoa aztertzen dute. Gainerako hiru probek (esaldiak ekoiztea eta ulertzea eta kasu eta posposizio sintagmak ekoiztea) maila semantiko-lexikoa eta morfosintaktikoa aztertzen dute. Guztira 160 estimulu daude (ikusi 1. eranskina). 


\subsection{Prozedura}

Haurrak euskara-gaztelania elebidunak zirenez, bi saiotan aztertuak izan ziren: saio bat hizkuntza bakoitzarentzat, gutieneko aste bateko tartearekin bi saioen artean. Saioen hizkuntza modu aleatorioan erabakitzen zen: lehena euskaraz eta bigarrena erdaraz, edo alderantziz. Denbora ez zen mugatua, ez zitzaien erran ahalik azkarrena erantzuteko. Hala ere, proba bakoitzari erantzuteko denbora grabatzen du fLEX aplikazioak (ikus 1. eranskinean proba bakoitzeko iraupenaren batezbestekoa). Garrantzizkoa da proben hurrenkera errespetatzea, esaldi berdinak erabiltzen direlako esaldi ekoizpenean eta ulermenean. Ulermen proban entzundako estimulu esaldiek ekoizpenean ez eragiteko, ezinbestekoa da ulermena ekoizpena eta gero aztertzea. Aplikazioa piztu eta probak automatikoki hasten dira, proba bakoitzarentzako jarraibideak ematen dira (ikusi 2. eranskina). Proba bakoitza hasi baino lehen hiru adibide ematen dira beti, egin behar dena ulertua dela segurtatzeko, eta ebaluatzaileak jarraibideak behar bezainbat aldiz errepika zitzakeen.

\subsection{Notazioa}

\subsubsection{Gauzak eta ekintzak izendatzea (fLEX1 eta fLEX2)}

Arazo fonologikoak ez dira kontatzen. Irudian agertzen den gauzari edo ekintzari dagokion izena edo aditz egokia ekoizten bada, orduan 1 ematen da. Aldiz, puntua ez da ematen ondoko kasuetan: beste hizkuntza batean ekoitzia bada («oiloa» $\rightarrow$ «gallina»; erori $\rightarrow$ resbalatu) ; semantikoki hurbila baina xede-hitza ez bada («oiloa» $\rightarrow$ «oilarra»; bete $\rightarrow$ edan) ; hitz baten ordez beste zerbait ekoiztea, adibidez, perifrasia bat («hautsi» $\rightarrow$ «ematen du martilloarekin»); aditz edo izen bat ekoiztea izen edo aditz baten ordez («jan» $\rightarrow$ «hezurra»). Guztira 30 puntu eman daitezke.

\subsubsection{Esaldi ekoizpena ( $f L E X 3)$}

Arazo fonologikoak ez dira kontatzen. Aditz laguntzaileen erabilpena aztertzeko, «ARI izan» forma saihestea komeni da, eta horregatik orainaldia erabiltzea eskatu da proba honetan. Hala eta guziz ere, gerta daiteke forma horiek agertzea, eta berez forma horiek zuzenak direnez, ez dira huts bezala jotzen (baina haien kopurua kontatzen da). Beraz, lehen urratsa «ari izan» formak, «xede» formak eta «beste» formak («ari izan» eta xede hitza ez diren formak) sailkatzean datza (ikusi «Emaitzak» atala).

Proba honek aditz flexioa bereziki aztertzen duenez, kasu ergatiboaren isiltzea ez da kontatzen (adb: txakurra hezurra jaten du); kode alternantzia izen sintagmetan edo aditzetan ere ez, aditza ongi jokatua baldin bada (adb: egunero txakurrak hartzen du hueso bat ; Gizonak konstruitzen du etxe bat). Osagai batzuk ez badira ekoizten baina aditza ongi jokatua bal- 
din bada, ontzat hartzen da (adb; «Mutikoak txapela kentzen dio»). Gainera, euskaraz hitz hurrenkera aski librea denez, ez zaio kasurik ematen aditza bukaeran egoteari ala ez. Aldiz, puntua ez da ematen ondoko kasuetan: aditza gaizki jokatzean edo ez jokatzean («mutilak loreak usaintzen ditu» $\rightarrow$ «loreak usaintzen du» ; «haurrak erortzen dira» $\rightarrow$ «umeak jausten»); xede-esaldia ekoiztearen ordez beste zerbait ekoiztea («mutilak loreak usaintzen ditu» $\rightarrow$ «umea bi baloiak hartzen du»); xede-aditz laguntzailea ez denean ekoizten, beste aditz bat erabiltzeagatik («gizona ateratzen da» $\rightarrow$ «gizonak agur esaten du»). Guztira 35 puntu eman daitezke.

\subsubsection{Esaldi ulermena (fLEX4)}

Entzundako esaldiari dagokion irudia erakusteak 1 ematen du. Aldiz, Distraitzaile Lexikoa (DL), Distraitzaile Flexionala (DF) edo Distraitzaile Mixtoa erakusteak 0 ematen zuen (ikusi 5. irudia adibidetzat). Guztira 35 puntu eman daitezke.

\subsubsection{Kasu eta posposizio-sintagmen ekoizpena}

Galderari erantzuten dion kasu edo posposizio-sintagma ekoizteak 1 ematen du. Aldiz, puntua ez da ematen ondoko kasuetan : beste kasu edo posposizio bat erabiltzean (adibidez, genitiboa destinatiboaren ordez : Norentzat da hezurra? $\rightarrow$ txakurrarena), edo kasua isiltzean (Norentzat da hezurra? txakurra). «Beste» hutsak ordezkatze edo isiltze hutsak ez diren hutsak dira; adibidez, beste erantzun bat ematea (Nori ematen dizkio haziak laborariak? *Gizon bat). Guztira 30 puntu eman daitezke.

\section{EMAITZAK}

Orokorki, emaitza apalenak esaldiak ekoizteko proban aurkitzen dira (\% 62), eta beste probetako emaitzak \% 80 ingurukoak dira (ikusi 3. eranskina). Ondoko parteetan, emaitza kuantitaboak (emaitza eta hutsen kopuruaren ehuneko batezbestekoa) eta kalitatezkoak (huts moten distribuzioa) aurkezten dira probaka eta sarreran aipatu ditugun ikerketa-ardatzen arabera: aditzen ekoizpena maila semantiko-lexikalean eta morfosintaktikoan; aditz jokatuen ekoizpena eta ulermena; kasu eta posposizio sintagmen ekoizpena.

\subsection{Aditzen ekoizpena maila semantiko-lexikalean eta morfosintaktikoan}

Aditzen ekoizpena maila semantiko-lexikalean eta morfosintaktikoan konparatzeko, fLEX2 (ekintzak izendatzea) eta fLEX3 (esaldi ekoizpena) 
probetako emaitzetan oinarritu gara. Orokorki, ekintzak izendatzeko emaitzak esaldiak ekoizteko emaitzak baino hobeak dira (\% $80>\%$ 62). Gainera, emaitzak aditz motaka aztertuz, ekintzak izendatzean, V1 aditzak V2 eta V3 aditzak ekoizteko baino apalagoak badira (V1 < V2, V3), esaldiak ekoiztean, V3 aditzak V1 eta V2 aditzak erabiltzeko baino apalagoak dira $(\mathrm{V} 3<\mathrm{V} 1, \mathrm{~V} 2)$.

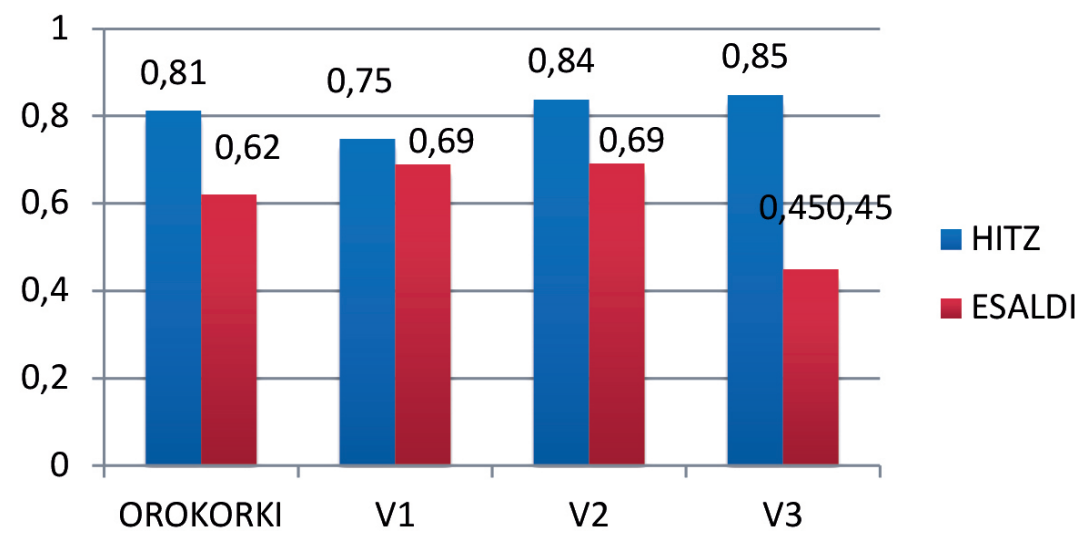

7. irudia. Aditzak izendatzeko eta jokatzeko emaitza onak orokorki eta aditz motaka (V1: Nor edo NORK aditzak; V2: NOR-NORK aditzak; V3: NOR-NORI-NORK aditzak).

\subsection{Esaldien ekoizpena eta ulermena}

Ekoiztu ziren 350 esaldietatik $(35 \times 10$ haur), \% 16 «ari izan» formak izan dira, \% 46 xede erantzunak eta $\% 37$ «beste» formak, 8 . irudiak erakusten duen bezala.

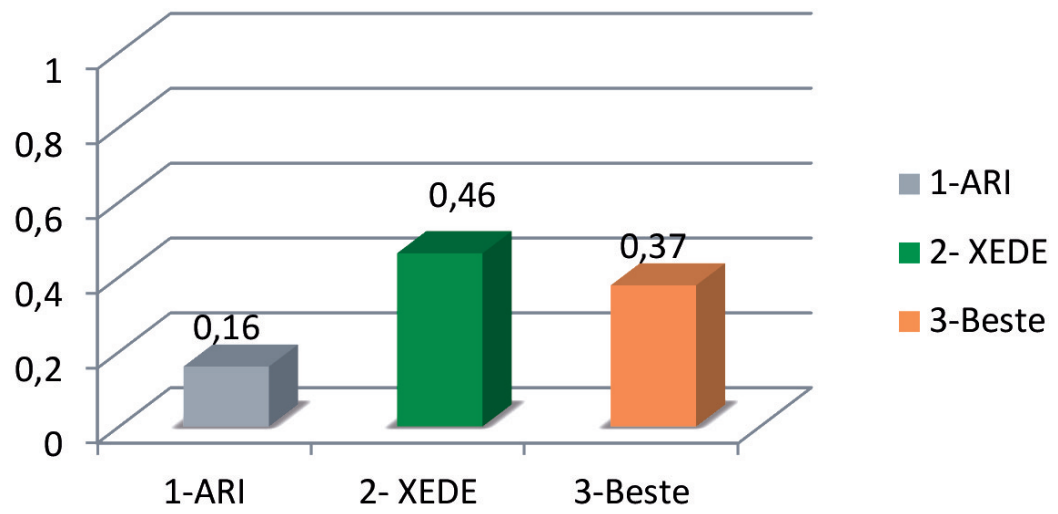

8. irudia. fLEX3ko emaitzak. Esaldi ekoizpena. 
«Beste» kategoriako formen artean daude: 1) erantzunik ez (\% 0,5); 2) isiltzea: aditz-laguntzailea edo aditza ez ekoiztea (\% 4); 3) fLEX: beste aditz bat ekoiztea (\% 6); 4) fLEX: beste aditz laguntzaile bat ekoiztea (\% 10); 5) «Besterik»: nahasketa bat (\% 16). 9. irudiak huts horien distribuzioa erakusten du aditz laguntzaile bakoitzarentzat; ikusten da «fLEX» huts motak gehien ukitzen dituen formak «ditu» eta «die» aditz laguntzaileak direla.

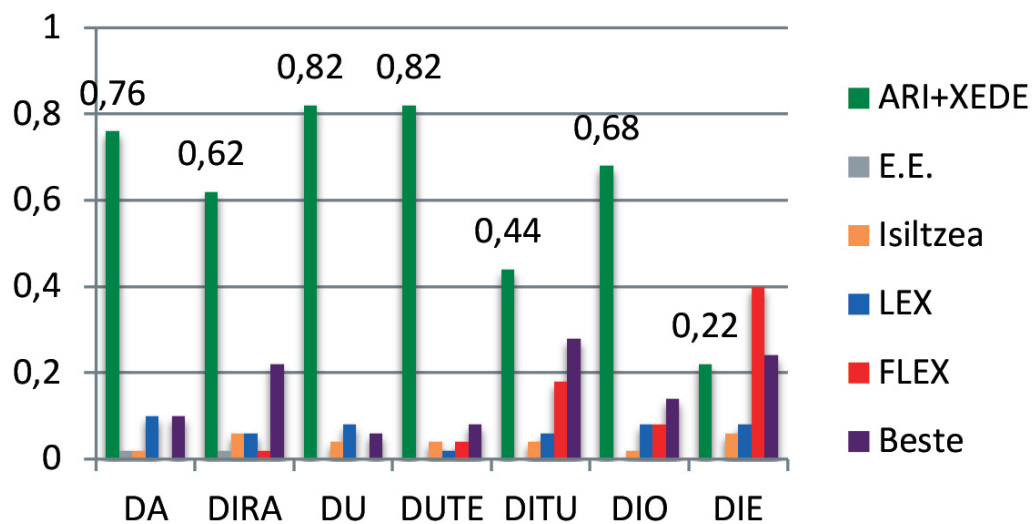

9. irudia. fLEX3ko emaitzak. Esaldi ekoizpena aditz laguntzaileka.

Bestalde, esaldiak ulertzeko, emaitzen batezbestekoa \% 84koa da, distraitzaile flexionala erakustea (\% 9), distraitzaile lexikala erakustea (\% 6), distraitzaile mixtoa $(\% 0,5)$ eta erantzunik ez $(\% 0,5)$. 10. irudiak erakusten du emaitza onen batezbestekoa (Xede) eta esaldi ulermeneko huts moten distribuzioa (distraitzaile lexikala DL, flexionala DF edo mixtoa DM) aditz laguntzaile bakoitzarentzat.

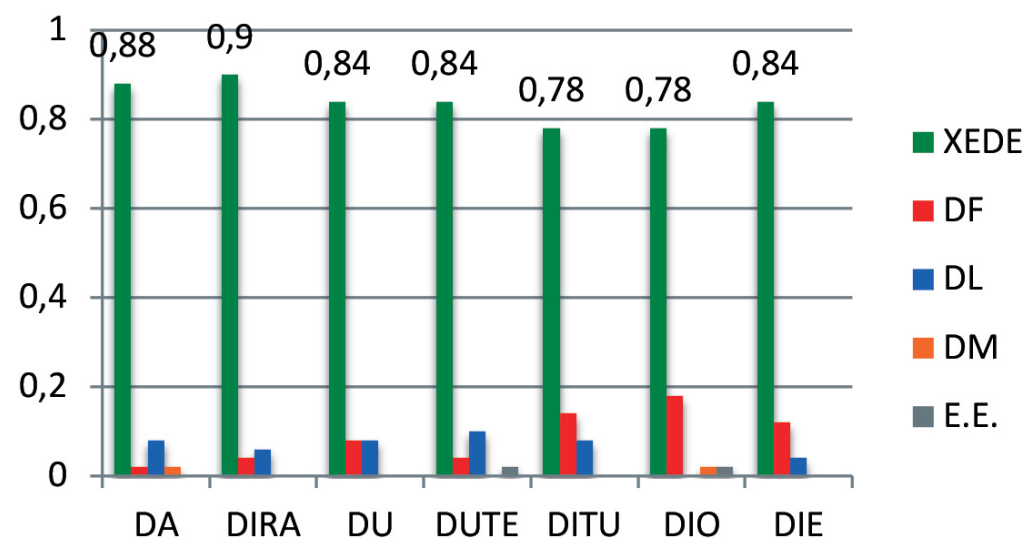

10. irudia. fLEX4ko emaitzak. Esaldi ulermena aditz laguntzaileka. 


\subsection{Posposizio sintagmen ekoizpena}

Posposizio sintagmak ekoizteko emaitzen batezbestekoa \% 79koa da, isiltze hutsen batezbestekoa \% 10koa eta ordezkatze hutsena \% 10koa. 11. irudiak huts moten distribuzioa erakusten du kasu mota bakoitzarentzat. Emaitza apalenak ergatiboa, destinatiboa eta lekuzko genitiboa kasuekin agertzen dira. Ergatiboak isiltze hutsak erakartzen dituelarik, destinatiboa eta lekuzko genitiboak ordezkatze hutsak erakartzen dituzte (adibidez, kasu genitiboa erabiltzea destinatiboaren ordez: Norentzat da hezurra? *txakurrarena.)

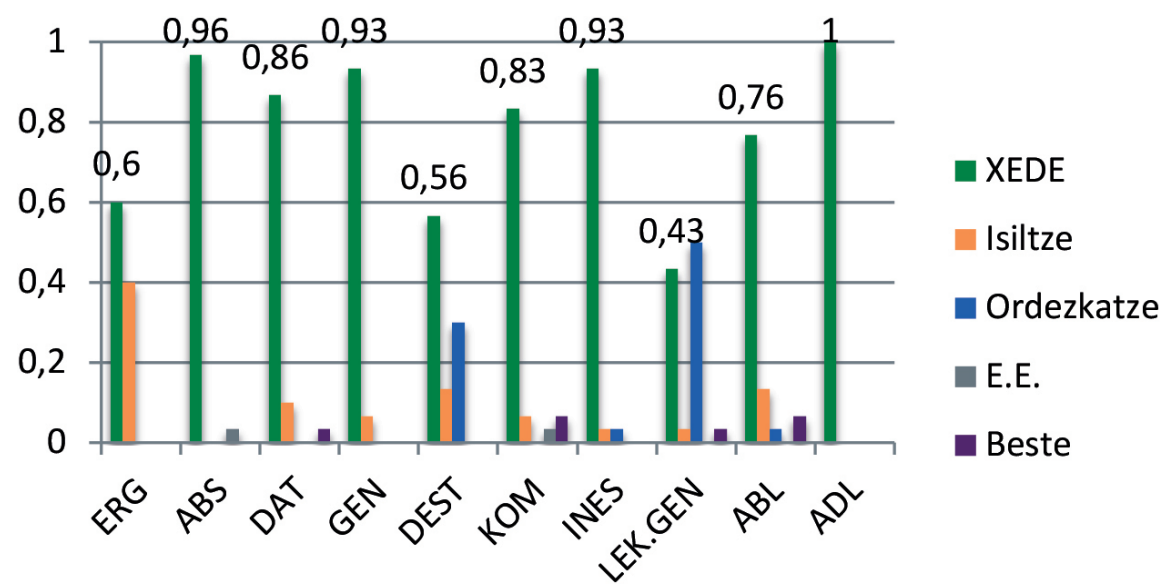

11. irudia. fLEX5eko emaitzak. Kasu eta posposizioen ekoizpena.

\section{EZTABAIDA ETA ONDORIOAK}

Lan honen helburua zen haur euskaldunengandik datuak biltzea fLEX oinarri hartuta, proba lexiko-semantiko eta morfosintaktikoetan, ekoizpenean zein ulermenean. Aurreikusten zen 5 urtetik gorako haurrak izen eta aditzak, testuinguru gramatikal baten barne edo kanpo, ekoizteko edota ulertzeko gai izango zirela. Oro har, haurrek jarraibideak ulertzeko zailtasun nagusirik ez dute erakutsi, baina emaitza ezberdinak ateratzen dira probaren arabera, aditz mota edo kasu motaren arabera.

Aurreikusten ez zen bezala, zailtasun batzuk agertu dira ekintza batzuk izendatzeko. Ekintzak izendatze probako emaitza apalenak NOR edo NOR-NORK motako aditzekin aurkitu dira: (handitu, lotsatu, erre, lurperatu). Gerta daiteke irudien bidez ekintza batzuk beste ekintza batzuk baino ekoitzarazten zailagoa izatea, eta orduan estimuluari lotua izatea. Bai eta maiztasunari ere lotua izatea. Hala ere, maiztasun txikikoak ez dira, baina 
maiztasun ezberdinetakoak bai. Esaldiak ekoizteko berriz, emaitza apalenak NOR-NORI-NORK motako aditzekin aurkitu dira. Emaitza horiek erakusten dute aditz mota eta hizkuntzaren atalak kontuan hartzea garrantzizkoa dela. Izan ere, erakusten dute ekintzak izendatzeko NOR-NORINORK aditz ditransitiboak ekoizteko arazo handirik ez dagoela (\% 85) baina esaldi batean erabiltzeko arazoak bai agertzen direla (\% 45).

Gainera, esaldiak ekoiztean, emaitzek erakusten dute «ditu» eta «die» aditz laguntzaileak direla Flex huts mota gehien dituzten formak, hots, aditz-laguntzailea gaizki erabiltzea (ditu: \% 18; die: \% 40). Aldi berean, forma horiek ulertzeko arazo handirik ez da ageri. Beraz, asimetria bat ikusten da esaldi ekoizpenaren eta ulermenaren proben artean (18). Probaren izaerari lot dakioke: esaldiak ulertzeko, irudien artean aukeratzea eskatzen denez, hutsak agertzea minimizatua liteke. Aldiz, esaldi ekoizpenaren proba irekiagoa denez, hutsak ekoizteko aukera gehiago utzi litzake. Ondorioz, ikerketak egiten jarraitu behar da eta datu gehiago bildu euskal aditz morfologiaren ekoizpen-ulermen asimetriaz ondorio sendoagoak ateratzeko.

Kasu eta posposizioen ekoizpenari dagokionez, ergatiboaren ekoizpena beste kasuen ekoizpena baino ahulago agertzen da, aurreikusten zen bezala. Aldiz, ez zen aurreikusten destinatiboa eta lekuzko genitibo posposizioak ekoizteak arazoak ekartzea. Datu hauek erakusten dute GT haurrengan ahuleziak badaudela prozesaketa gramatikalean, proba esperimentalak erabiltzen direnean.

Lan honek erakusten du, batetik, fLEX proba pasatzeak ez diela arazorik sortzen 5 urtetik gorako haurrei, baina, aldi berean, proba motaren arabera eta hizkuntza atalaren arabera zailtasun maila aldakorra dela. Partaide talde handiago batengandik eta kontrolatu batengandik datu gehiago biltzea garrantzizkoa litzateke datu oinarri bat osatzeko hizkuntza arazoak dituzten haurrek ahulezia berdinak erakusten dituzten definitzeko. Arazotsuak diren estimuluak aldatuz, fLEX estandarizatu beharko litzateke, normak definitzen hasteko lagin handi baten oinarrian. Estimuluak ezaugarri zehatz batzuen oinarrian (maiztasuna, hitzen luzera, kognatua izan ala ez izan) kontrolatu beharko dira, ikerketan sakontzeko. Gainera, euskaldunak elebidunak direnez, baliagarria da elebitasun maila eta euskararen ezagutza kontrolatzea talde homogeneoak osatzeko. Erabili genuen galdetegiko erantzunak aita-amen ebaluazioan oinarritzen ziren, baina amak edo aitak goretsi dezake haurraren gaitasuna edo kuantitatiboki ezberdinki zenbatu hizkuntza bakoitzaren esposizioa. Ahal bezain galdetegi objektiboa erabili beharko litzateke. Euskararen esposizio edota ezagutza apala duten haurren jarrera aztertzea beharrezkoa litzateke, hala eta guziz ere, hizkuntza arazo batekin zertan ezberdintzen den definitzeko. Halako ikerketak balio handikoak dira psikohizkuntzalaritza eta hizkuntzalaritza klinikoaren ikuspegitik, gure gizarte eleanitzetan $[6,7,18]$. 


\section{BIBLIOGRAFIA}

[1] POURQUIE, M., LACROIX, H., KARTUSHINA, N. (2018) «Investigating vulnerabilities in grammatical processing of bilinguals: Insights from Basque-Spanish adults and children.» Linguistic Approaches to Bilingualism.

[2] BASTIAANSE, R., RISPENS, J., RUIGENDIJK, E., RABADÁN, O. J., \& THOMPSON, C. K. (2002). «Verbs: some properties and their consequences for agrammatic Broca's aphasia». Journal of Neurolinguistics, 15(3-5), 239264.

[3] LEONARD, L. B. (2014). «Specific Language Impairment across languages». Child Development Perspectives, 8(1), 1-5.

[4] LAKA, I. (2003). «Agramatismoaren sintomak euskaraz». In J.M. Makatzaga \& B. Oyharçabal (Eds.), IKER 14(1) Euskal gramatikari eta literaturari buruzko ikerketak XXI mendearen atarian (pp. 323-341). Baiona, IKER (CNRS)-Euskaltzaindia.

[5] POURQUIE, M. (2013). «Verb processing in Basque and French agrammatic aphasia: A 'post-lexical access' déficit». Aphasiology, 27(12):1472-1510.

[6] ARMON-LOTEM, S., DE JONG, J., MEIR, N. (2015). Assessing multilingual children: Disentangling bilingualism from language impairment (Vol. 13). Multilingual matters.

[7] MARINIS, T. (2017). «Language Impairment in Bilingual children: State of the art 2017.» Linguistic approaches to bilingualism, 7(3-4), 265-276.

[8] GARCIA, I., BARREÑA, A., EZEIZABARRENA, M. J., ALMGREN, M., ARRATIBEL, N., BARNES, J., \& UNIBERTSITATEA, M. (2014.). «Haur euskaldunen komunikazio-garapena neurtzen 30-50 hilabete bitartean: MacArthur-Bates CDI-III tresnaren euskal bertsioa», 43. Uztaro, 88, 33-72.

[9] EZEIZABARRENA M. J. (1996), Adquisición de la morfología verbal en euskera y castellano por niños bilingues, Bilbo, Euskal Herriko Unibertsitateko Argitalpen Zerbitzua.

[10] BARREÑA A. (1995), Gramatikaren jabekuntza-garapena eta haur euskaldunak, Bilbo, Euskal Herriko Unibertsitateko Argitalpen Zerbitzua.

[11] ELOSEGI, Kristina (1998). Kasu eta preposizioen jabekuntza-garapena haur elebidun batengan, Euskal Herriko Unibertsitatea, Bilbo.

[12] LARRAÑAGA, P. (1994). «La evolución del caso en euskera y castellano». In J. Meisel (ed), La adquisición del vasco y del castellano en niños bilingues. Frankfurt am Main, Germany: Vervuert.

[13] EZEIZABARRENA M. J. \& LARRAÑAGA P. (1996), «Ergativity in Basque: a problem for language acquisition?», Linguistics, 34, 955-991.

[14] AUSTIN, J. (2009). «Delay, interference and bilingual development: The acquisition of verbal morphology in children learning Basque and Spanish.» International Journal of Bilingualism, 13(4), 447-479.

[15] MANTEROLA, I. \& ALMGREN, M. (2015). «Quelques traits du développement du basque L2 en contexte de revitalisation de la langue à travers l'immersion scolaire.» Revue suisse des sciences de l'éducation, 37(1) 24-42. 
[16] EZEIZABARRENA, M. J., MANTEROLA, I., \& BELOKI, L. (2009). «Euskara $\mathrm{H} 2$ goiztiarraren ezaugarrien bila: adizkiak eta gramatika-kasuak haurren ipuin-kontaketetan». Euskera, 54, 2-1.

[17] BARREÑA, A.; EZEIZABARRENA, M.J. \& GARCÍA, I. (2008). «Entzundako hizkuntzaren eragina haur euskaldun txikien gramatika-garapenean». In X.Artiagoitia \& J. Lakarra (eds.) 2008, Patxi Goenagaren omenez. Gramatika Jaietan, 93-113.

[18] POURQUIE, M., (2017). «Erreurs produites par des enfants bilingues à développement typique et atypique du langage: qu'est-ce qui les distingue?». In Bogliotti, Isel \& Lacheret Dujour (Ed.), Atypies langagières de l'enfance à l'âge adulte. Apport de la psycholinguistique et des neurosciences cognitives, 51-75. De Boeck Superieur publishers. ISBN 9782353273942.

\section{ERANSKINAK}

1. eranskina. Argumentu-egitura mota ezberdinetako aditz ez jokatuak.

\begin{tabular}{l|l|l}
\hline \multicolumn{1}{c|}{1 argumentu } & \multicolumn{1}{|c}{2 argumentu } & \multicolumn{1}{c}{3 argumentu } \\
\hline To fall & To eat (sth) & To give (sth to sb) \\
Caer & Comer & Regalar \\
Tomber & Manger & Offrir \\
Erori & Jan & Eskaini \\
\hline
\end{tabular}

Argumentu-egitura mota ezberdinetako aditz jokatuak ( $\mathrm{S}=$ Subjektua; $\mathrm{O}=$ Objektua; $\mathrm{D}=$ Datiboa; $3 \mathrm{~s}=3$. pertsona singularrean; $3 \mathrm{p}=3$. pertsona pluralean)

\begin{tabular}{|c|c|c|}
\hline 1 argumentu & 2 argumentu & 3 argumentu \\
\hline He falls. [S3s] & $\begin{array}{l}\text { He eats something. } \\
{[\mathrm{S} 3 \mathrm{~s}]}\end{array}$ & $\begin{array}{l}\text { He gives something to someone. } \\
{[\mathrm{S} 3 \mathrm{~s}]}\end{array}$ \\
\hline $\begin{array}{l}\text { Cae. } \\
{[\mathrm{S} 3 \mathrm{~s}]}\end{array}$ & $\begin{array}{l}\text { Lee algo. } \\
{[\mathrm{S} 3 \mathrm{~s}]}\end{array}$ & $\begin{array}{l}\text { Ofrece algo a alguien. } \\
{[\mathrm{S} 3 \mathrm{~s}]}\end{array}$ \\
\hline $\begin{array}{l}\text { Il tombe. } \\
\text { [S3s] }\end{array}$ & $\begin{array}{l}\text { Il mange quelquechose. } \\
\text { [S3s] }\end{array}$ & $\begin{array}{l}\text { Il offre quelquechose à quelqu'un. } \\
\text { [S3s] }\end{array}$ \\
\hline$\frac{\text { Erortzen da. }}{[\mathrm{S} 3 \mathrm{~s}]}$ & $\frac{\text { Jaten du zerbait. }}{[\mathrm{S} 3 \mathrm{~s}-\mathrm{O} 3 \mathrm{~s}]}$ & $\frac{\text { Eskaintzen dio zerbait norbaiti. }}{[\mathrm{S} 3 \mathrm{~s}-\mathrm{O} 3 \mathrm{~s}-\mathrm{D} 3 \mathrm{~s}]}$ \\
\hline
\end{tabular}


2. eranskina. fLEXeko probak, bakoitzari dagokion estimulu kopurua, eta proba bakoitzeko denboraren batezbestekoa.

\begin{tabular}{lcc}
\hline \multicolumn{1}{c}{ fLEX } & $\begin{array}{c}\text { Estimulu } \\
\text { kopurua }\end{array}$ & $\begin{array}{c}\text { Denboraren } \\
\text { batezbestekoa }\end{array}$ \\
\hline 1 Gauzak izendatzea & 30 & $02: 14$ \\
2 Ekintzak izendatzea & 30 & $03: 02$ \\
3 Esaldiak ekoiztea & 35 & $05: 04$ \\
4 Esaldiak ulertzea & 35 & $02: 25$ \\
5 Kasu eta posposizio sintagmak ekoiztea & 30 & $03: 10$ \\
\hline Guztira & 160 & $15: 55$ \\
\hline
\end{tabular}

3. eranskina. fLEX probetako jarraibideak.

\begin{tabular}{|c|c|}
\hline fLEX & Jarraibideak (aplikazioan grabatuak) \\
\hline $\begin{array}{c}1 \\
\text { Gauzak izendatzea }\end{array}$ & $\begin{array}{l}\text { «Irudi bat ikusiko duzu eta erran beharko duzu zer den; hemen, adi- } \\
\text { bidez: «arraina»; «soinekoa»; «txirrindula». Ulertu duzu? Has gai- } \\
\text { tezen!» }\end{array}$ \\
\hline $\begin{array}{c}2 \\
\text { Ekintzak izendatzea }\end{array}$ & $\begin{array}{l}\text { «Irudi bat ikusiko duzu eta erran beharko duzu zer egiten ari diren; } \\
\text { hemen, adibidez: «patinatu» erran behar da; «erasiatu» edo «zi- } \\
\text { gortu»; «galdatu» edo «eskatu» Ulertu duzu? Has gaitezen!» }\end{array}$ \\
\hline $\begin{array}{c}3 \\
\text { Esaldiak ekoiztea }\end{array}$ & $\begin{array}{l}\text { «Irudi bat ikusiko duzu eta kondatu behar duzu zer gertatzen den, } \\
\text { esaldi oso bat eginez; hemen, adibidez: «Gizonak patinatzen du.» } \\
\text { Esaldi osoa erran behar duzu. «Aitamek haurra zigortzen dute.»; } \\
\text { «Mutikoak gizonari ordua eskatzen dio.» Ulertu duzu? Has gaite- } \\
\text { zen!» }\end{array}$ \\
\hline $\begin{array}{c}4 \\
\text { Esaldiak ulertzea }\end{array}$ & $\begin{array}{l}\text { «Lau irudi ikusiko dituzu eta ukitu behar duzu entzungo duzun } \\
\text { esaldiari dagokion irudia. Adibidez:»Usteltzen dira.» Zein irudi } \\
\text { da? Hau da!; «Kamiseta hautatzen du.» Zein irudi da? Hau da!; Ilea } \\
\text { mozten die.» Zein irudi da? Hau da! Ulertu duzu? Has gaitezen!» }\end{array}$ \\
\hline $\begin{array}{c}5 \\
\text { Posposizio } \\
\text { sintagmak ekoiztea }\end{array}$ & $\begin{array}{l}\text { «Irudia ikusiz, erantzun behar diozu galderari. Adibidez: «Nork ja- } \\
\text { ten du goxokia?» - Mutikoak. «Zerekin idazten da?» - arkatzare- } \\
\text { kin. «Nun dago kabia?» -Zuhaitzean. Ulertu duzu? Has gaitezen! } \\
\text { Entzun ezazu galdera eta erantzun!» }\end{array}$ \\
\hline
\end{tabular}


4. eranskina. fLEX bost probetako emaitza orokorrak.

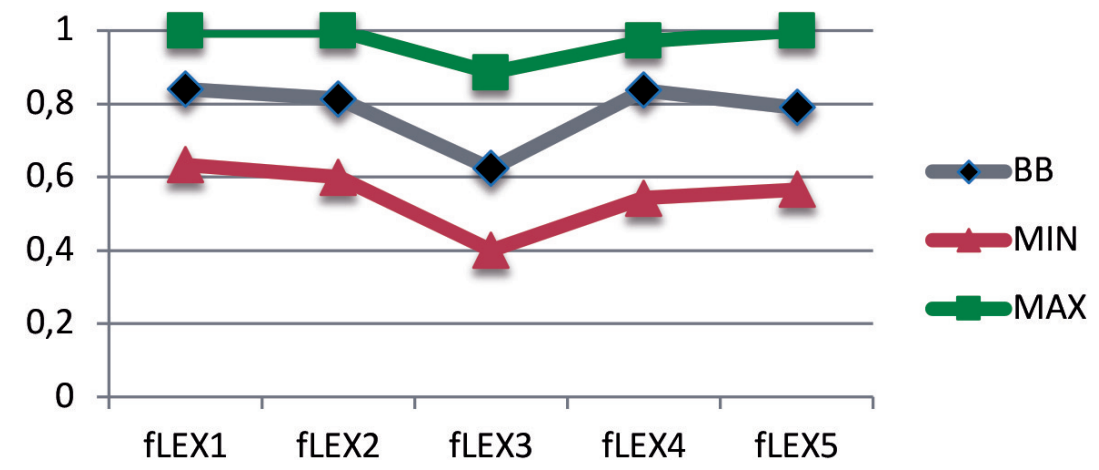

$\mathrm{BB}=$ Batezbestekoa MIN = Minimoa MAX = Maximoa. 